\title{
Vetten: machtige moleculen
}

Citation for published version (APA):

Mensink, R. P. (2000). Vetten: machtige moleculen. Universiteit Maastricht.

https://doi.org/10.26481/spe.20001108rm

Document status and date:

Published: 08/11/2000

DOI:

10.26481/spe.20001108rm

Document Version:

Publisher's PDF, also known as Version of record

\section{Please check the document version of this publication:}

- A submitted manuscript is the version of the article upon submission and before peer-review. There can be important differences between the submitted version and the official published version of record.

People interested in the research are advised to contact the author for the final version of the publication, or visit the DOI to the publisher's website.

- The final author version and the galley proof are versions of the publication after peer review.

- The final published version features the final layout of the paper including the volume, issue and page numbers.

Link to publication

\footnotetext{
General rights rights.

- You may freely distribute the URL identifying the publication in the public portal. please follow below link for the End User Agreement:

www.umlib.nl/taverne-license

Take down policy

If you believe that this document breaches copyright please contact us at:

repository@maastrichtuniversity.nl

providing details and we will investigate your claim.
}

Copyright and moral rights for the publications made accessible in the public portal are retained by the authors and/or other copyright owners and it is a condition of accessing publications that users recognise and abide by the legal requirements associated with these

- Users may download and print one copy of any publication from the public portal for the purpose of private study or research.

- You may not further distribute the material or use it for any profit-making activity or commercial gain

If the publication is distributed under the terms of Article $25 \mathrm{fa}$ of the Dutch Copyright Act, indicated by the "Taverne" license above, 


\title{
Vetten: machtige moleculen
}

\author{
Rede
}

in aangepaste vorm uitgesproken bij de aanvaarding van het ambt van bijzonder hoogleraar Moleculaire Voedingskunde, met bijzondere aandacht voor het lipidenmetabolisme, aan de Universiteit Maastricht op 8 november 2000

door

Dr. Ir. Ronald P. Mensink 
(C) 2000, R.P. Mensink

ISBN 90-5681-092-8

De leerstoel "Moleculaire Voedingskunde, met bijzondere aandacht voor het lipidenmetabolisme" is mede mogelljk gemaakt door de Stichting Zuivel, Voeding en Gezondheid te Maarssen

Druk en printwerk: Unigraphic, Maastricht 
Ter nagedachtenis aan mijn vader, Voor mijn moeder, Voor Dianne 

Mijnheer de Fector:

Zeer geachte Dames en Heren,

$\mathrm{Na}$ afloop van miln oratie is er een receptie. Ongetwijfeld dat er mensen in de zaal zitten die daar nu al naar uitkijken, maar die ook vastbeslaten zijn om zich in te houden, omdat ze op hun gewicht willen letten. Nu zijn ze dan ook vastberaden om dadelijk de vette hapjes aan zich voorbij te laten gaan. Aan het einde van de receptie zullen sommige mensen toch moeten erkennen, dat ze meer hebben gegeten dan vooraf de bedoeling was: de vetrijke hapjes waren te machtig. Dat geeft een onprettig gevoel. De eetlust voor de avondmaallijd is bedorven; terwijl de algemene gedachte ook nog eens is, dat je van teveel vet in de voeding dik wordt en hart- en vaatziekten krijgt. Of dat echt zo is, wil ik nu even in het midden laten, maar zall hier later in mijn voordracht op terugkomen. Vetten zijn echter veel meer dan alleen smaakmakers. Zo zijn ze bijvoorbeeld onmisbaar voor de opbouw van gezonde cellen en zijn ze betrokken bij het aansturen van vele lichaamsprocessen. $Z e$ vervulien dus een machtige rol voor een gezond bestaan. Als u minder vet wilt gaan eten, dan zijn er vele mogelijkheden om hier aandacht aan te besteden. In de winkel treft $u$ immers vele voedingsmiddelen aan met een verlaagd vetgehalte of met "beter" vet. Het ontwikkelen en produceren van voedingsmiddelen met een zodanige vetsamenstelling, dat de consument ze wil kopen, is voor de industrie dan ook van eminent belang om te overleven. Het is zelfs $z_{0}$, dat de aandelenkoersen van bedrijven mede athankellik zijn of hun producten al dan niet worden toegelaten op de markt. Wederom, de rol van vetten is machtig.

Dit zijn slechts enkele voorbeelden, waaruit blijkt dat voedingsvetten op vele terreinen thun macht laten gelden. Tevens zijn vetten een machtig mooi onderwerp om onderzoek mee te doen. In 1985 werd $/ k$ aangesteld 
als promotle-assistent bij de toenmalige vakgroep Humane Voeding van de Landbouwuniversiteit te Wageningen. In mijn promotieonderzoek stonden de effecten van voedingsvetten op het cholesterolgehalte in het bloed centraal. In 1990 ben ik naar Maastricht gegaan, waar ik de mogelijkheld heb gekregen om verder onderzoek te verrichten. Vetten bleven echter een centrale plaats innemen. $U$ vraagt zich dan ook misschien af of - nu we 15 jaren verder zijn - nog niet alles op dit gebled bekend is. Ik moet $u$ helaas teleurstellen: wij hebben nog veel te leren. In deze rede wil ik u dan ook een indruk geven van hetgeen wij wel weten, maar ook van hetgeen wij niet weten en hoe wil dit te weten willen komen. Dit will ik onder andere doen aan de hand van voorbeelden uit mijn eigen onderzoek, waarin de rol van voedingsvetten op risicofactoren voor hart- en vaatziekten centraal staat. I $k$ wil hiermee allerminst pretenderen, dat wij de enige in de wereld zijn die onderzoek op dit terrein verrichten, of dat onze resultaten de absolute waarheid zilin, of dat voedingsvet de enige voedingsstof is die het risico op hart- en vaatziekten beïnvloedt. I $k$ wil er met name mee bereiken, dat u een idee krijgt over mijn onderzoek en mijn leeropdracht, de "Moleculaire Voedingskunde, met bijzondere aandacht voor het lipidenmetabolisme".

\section{Voedingsvetten}

Wat wordt nu eigenlijk onder vetten verstaan?

Vetten zijn stoffen, die slecht oplosbaar zijn in water, maar goed in organische oplosmiddelen, zoals chloroform en hexaan. Het is niet zo, dat er maar sprake is van éen vet. Er zitten in de voeding vele stoffen, die aan dit criterium voldoen en dus allemaal vetten zijn.

Een bekend vet zijn de zogenaamde triglyceriden, die opgebouwd zijn uit één glycerolmoleculle en drie vetzuurmoleculen. Het zijn nu deze vetzuren, die energle leveren. De aanbevolen bijdrage van vet aan de energle-inname ligt tussen de 30 en 35 energieprocent [1]. De 
gemiddelde hoeveelheid vet in de voeding van een volwassene is lets hoger: zo'n 36 procent, hetgeen overeenkomt met 90 gram vet. Dit vet is niet alleen terug te vinden in vetten, oliën en hartige sauzen, maar ook in vlees, in zuivelproducten, in noten, zaden en snacks, on in gebak en koek. Ongeveer 75 procent van dit vet is afkomstig van voedingsmiddelen, die thuis worden gegeten of van huis uit worden meegenomen, bijvoorbeeld naar het werk [2].

Vetzuren zijn echter meer dan alleen een energiebron, zoals ik later zal toelichten. Ook is het éne vetzuur, het andere niet. Zo wordt er een onderscheid gemaakt tussen verzadigde vetzuren, enkelvoudig onverzadigde vetzuren en meervoudig onverzadigde vetziuren. Verzadigde vetzuren hebben een hoog smeltpunt. Dit betekent, dat $u$ ze met name aantreft in "vaste" vetten. Producten, die bij koelkasttemperatuur zo hard zijn, dat er bijna geen boterham mee te smeren valt, zijn dan ook rijk aan verzadigde vetzuren. Ook kunt $u$ ze aantreffen in vette vleessoorten. Enkelvoudig en meervoudig onverzadigde vetzuren hebben een lager smeltpunt. Dus bij een lage temperatuur zijn ze smeerbaar of zelf́s vloeibaar. De meeste oliën zijn dan ook rijk aan onverzadigde vetzuren.

Er zijn ook vetten in de voeding aanwezig, die weliswaar geen energle leveren, maar toch in het lichaam een essentiële rol vervullen. $\mathrm{Te}$ denken valt aan cholesterol. Cholesterol heeft een slechte naam, omdat een hoog cholesterolgehalte in het bloed een risicofactor is voor hart- en vaatziekten. Maar cholesterol is ook nodig voor vele lichaamsfunctles. Zo speelt het een belangrijke rol bij de bouw van celwanden, terwijl het lichaam uit cholesterol ook stoffen maakt, die voor een optimaal functioneren noodzakelijk zijn. De mens maakt ook zelf cholesterol: zij vertrouwt niet alleen op een adequate toevoer via de voeding. Planten maken geen cholesterol, maar stoffen die daarop lijken. Deze stoffen, die wij ook via de dagelijkse voeding binnenkrijgen, worden plantaardige 
sterolen genoemd.

Ook sommige vitamines behoren tot de vetten. Vitamine $E$ is een bekend voorbeeld. Het vervult in ons lichaam onder andere een rol als antioxidant, waardoor het radicalen onschadelijk kan maken. Radicalen zljin stoffen, die in het lichaam door reacties met zuurstof ontstaan en een schadelijke werking kunnen hebben.

In de voeding zitten nog veel meer vetten. Ik wil me echter tot deze voorbeelden beperken, waaruit blijkt dat vetten niet alleen maar als energiebron moeten worden gezien. Vetten zijn een onmisbaar bestanddeel van onze voeding, betrokken bij vele lichaamsprocessen, en essentleel voor een gezond bestaan.

Het wordt vaak aanbevolen om minder vet te eten, maar waarom eigenlijk? Heeft dat lets te maken met de effecten van vetten in de voeding op een belangrijke risicofactor voor hart-en vaatziekten: het cholesterolgehalte in het bloed?

\section{Vetzuren en het cholesterolgehalte}

Reeds in de jaren vijftig heeft een Amerikaanse onderzoeksgroep onder leiding van Professor Ancel Keys studies uitgevoerd, waarin de effecten van vetzuren in de voeding op het cholesterolgehalte werden bestudeerd. In deze studies kregen gezonde mannen voedingen met verschillende hoeveelheden en soorten vetten te eten. Dit waren zeer zorgvuldig uitgevoerde studies, waar nog steeds veel waardering en bewondering voor is. Zo werden bijvoorbeeld alle maaltijden aan de mannen verstrekt; zodat precies bekend was wat zij hadden gegeten. Nadat de mannen de voedingen gedurende enkele weken hadden gegeten, werd bloed afgenomen. In dit bloed werd het cholesterolgehalte bepaald. Hierdoor was het uiteindelijk mogelijk om te 
voorspellen op welke wijze het cholesterolgehalte in het bloed zou veranderen als gevolg van een veranderde vetinneming. Wat bleek nu? Het was niet de totale hoeveelheid vet in de voeding, die het cholesterolgehalte in het bloed bepaalde: de vetzuursamenstelling was veel belangrijker. In vergelijking met een voeding rijk aan koolhydraten; verhoogde een voeding rijk aan verzadigde vetzuren het cholesterolgehalte in het bloed. Meervoudig onverzadigde vetzuren hadden een cholesterolverlagend effect. Aan enkelvoudig onverzadigde vetzuren werd geen belangrijke rol toebedeeld. Zij verlaagden wellswaar het cholesterolgehalte ten opzichte van verzadigde vetzuren, maar een grotere cholesteroldaling kon worden bewerkstelligd indien de verzadigde vetzuren werden vervangen door meervoudig onverzadigde vetzuren [3].

Later werd duidelijk, dat het risico op hart- en vaatziekten niet alleen werd bepaald door de totale hoeveelheild cholesterol in het bloed. Cholesterol wordt door de bloedbaan getransporteerd door zogenaamde lipoproteïnen. Vetten en water zijn slecht mengbaar. Met andere woorden, met de beste wil van de wereld is het niet mogelijk om cholesterol en bloed te mengen. Dit zou betekenen, dat het onmogelljk zou zijn om het cholesterol door de bloedbaan te transporteren. Gelukkig is hiervoor een oplossing gevonden in de vorm van lipoproteïnen. Dit zijn deeltjes die het cholesterol afschermen van het waterige milieu, zodat het toch door de bloedbaan kan worden vervoerd. Twee belangrijke lipoproteinen zijn de zogenaamde lage dichtheids: lipoproteïnen ( $L D L)$ en de hoge dichtheidslipoproteïnen (HDL). Om het risico op hart- en vaatziekten in te schatten, is het van belang om een onderscheid te maken tussen het totaal-, het LDL. en het HDLcholesterolgehalte. LDL-cholesterol wordt ook wel omschreven als het "slechte" cholesterol, omdat een hoog LDL-cholesterolgehalte het risico op hart- en vaatziekten verhoogt. HDL-cholesterol is het zogenaamde 
"goede" cholesterol, omdat een hoog HDL-cholesterolgehalte het risico op hart- en vaatziekten juist lijkt te verlagen. In Nederland wordt dan ook, behalve naar de totale hoeveelheid cholesterol in het bloed, ook gekeken naar de hoeveelheid HDL-cholesterol om het risico op hart-en vaatzlekten in te schatten. Het is dus zeer wel mogelijk dat het cholesterolgehalte in het bloed niet uitzonderlijk hoog is, maar dat de hoeveelheid HDL-cholesterol laag is. Dit betekent dus dat de verhouding tussen het totaallcholesterolgehalte en het HDL-cholesterolgehalte in het bloed (totaalcholesterol:HDL-cholesterolverhouding) hoog is en dat wordt als ongunstig gezien. Het streven is dan ook om deze verhoudling te verlagen [4].

Hoe dit met vetzuren en koolhydraten kan worden bereikt, vormde de basis van mijn promotieonderzoek. Effecten op het totaalcholesterolgehalte waren dan weliswaar bekend, maar wat waren nu de effecten van vetzuren en koolhydraten op de verdeling van het cholesterol over het "slechte" LDL en het "goede" HDL? Kort samengevat werd gevonden, dat oliezuur - dit is het meest voorkomende enkelvoudig onverzadigde vetzuur in de voeding - een gunstiger effect had op de verdeling van het cholesterol over het "goede" HDL en het "slechte" LDL dan koolhydraten [5]. Het was dus niet terecht om ollezuur en koollhydraten over éên kam te scheren, zoals Professor Keys had gedaan [3]. Ze hebben weliswaar een vergelijkbaar effect op het totaalcholesterolgehalte, maar niet op de totaalcholesterol:HDLcholesterolverhouding. Ook bleek dat in dit opzicht de effecten van ollezuur en linolzuur - het meest voorkomende meervoudig onverzadigde vetzuur in de voeding - vergelijkbaar waren [6].

Het is dus niet nodig om bil voedingsadviezen het accent te leggen op een nog verdere verhoging van de linolzuurinneming, die momenteel bijna zeven energieprocent bedraagt [2]. Ollezuur is immers ook goed. De belangrijkste boodschap is dan ook, dat de hoeveelheid verzadigde 
vetzuren (en trans-vetzuren) in de voeding omlaag moet [4]:

Maar zijn nu alle verzadigde vetzuren slecht?

In de voeding komen met name vier verzadigde vetzuren voor: laurinezuur, myristinezuur, palmitinezuur en stearinezuur. Behalve in vetten en oliën, komen ze ook voor in producten, die waardevolle voedingsstoffen bevatten, zoals bijvoorbeeld zuivel en vlees. Ook zijn deze vetzuren noodzakelijk om van een vloeibare olle een liets hardere, smeerbare, margarine te maken en om andere producten te bereiden met een goede smaak en consistentie. Zo is het vaak onmogelijk om smakelijke producten te maken op basis van een vloeibare olie. $\mathrm{Na}$ bereiding zou de olie er aan alle kanten uitdruipen en dat is niet echt smakelijk. Het oog en de neus willen immers ook wat en spelen een niet te onderschatten rol bij de keuze van voedingsmiddelen. Het is dus noch mogellijk, noch gewenst om alle verzadigde vetzuren uit de voeding to bannen. Soms is het wel mogelijk om in vetten, ollën of producten het éne verzadigde vetzuur te vervangen door het andere verzadigde vetzuur. Dit soort technologische hoogstandjes heeft natuurlijk alleen zin, indien de verzadigde vetzuren verschillende gezondheidskundige effecten hebben. Wij hebben dan ook de effecten van drie verzadigde vetzuren onderzocht op enkele risicofactoren voor hart- en vaatziekten [7]. Het bleek dat in vergelijking met koolhydraten noch laurinezuur; noch myristinezuur, noch palmitinezuur een ongunstig effect heeft op de totaalcholesterol:HDL-cholesterolverhouding. Deze verzadigde vetzuren verhoogden weliswaar het totaalcholesterolgehalte, maar dit was ten dele te verklaren door een verhoging van het "goede" HDL-cholesterol Uit andere studies was reeds gebleken, dat stearinezuur weinig invloed heeft op het cholesterolgehalte [8]. Dit heeft ertoe geleid, dat stearinezuur als een neutraal vetzuur werd gezien en dat er soms voor gepleit is om stearinezuur niet als en "slecht" verzadigd vetzuur te oormerken. Met de term neutraal werd echter bedoeld, dat het eenzelfde 
effect heeft op het cholesterolgehalte als koolhydraten. Het geeft geen informatie of er een verschuiving is opgetreden van het "slechte" naar thet "goede" cholesterol. Het lijkt er echter op, dat de effecten van stearinezuup op de totaalcholesterol:HDL-cholesterolverhouding vergelijkbaar zijn met die van koolhydraten [9]. Betekent dit nu, dat verzadigde vetzuren helemaal geen ongunstig effect hebben? Nee, onverzadigde vetzuren hebben nog altijd een gunstiger effect op de totaalcholesterol:HDL-cholesterolverhouding. Betekent dat dan weer ${ }_{i}$ dat we niet minder vet moeten gaan eten, maar ander vet om het risico op hart- en vaatziekten te verlagen? Wederom nee, omdat we ons moeten realiseren, dat slechts éen risicofactor voor hart- en vaatziekten is besproken. Maar welke risicofactoren pleiten dan wel voor een verlaging van de vetconsumptie?

\section{Vetzuren en arteriële trombose}

Een ander belangrijke risicofactor voor hart- en vaatziekten is de arteriële tromboseneiging van het bloed. Bij het trombotische proces spelen bloedplaatjes een belangrijke rol. Als u zich bijvoorbeeld in de vinger heeft gesneden, dan zorgt de wond ervoor dat bloedplaatjes gaan samenklonteren, een proces dat ook wel wordt aangeduid met bloedplaatjesaggregatie. Daarna worden de bloedplaatjes stevig aan elkaar vastgeplakt: het bloed gaat stollen en er ontstaat een bloedstolsel oftewel trombus. Het eindresultaat is, dat het bloeden stopt. Dit klinkt mool, en het is ook mooi, maar het kan minder mooi zijn als dit in een slagader oftewel arterie gebeurt. Arteriën zljn bloedvaten, die organen en weefsels van zuurstof en andere voedingsstoffen voorzien. Een bekende arterie is de kransslagader, die het hart van voedingsstoffen voorzlet. Indien de vaatwand van een slagader beschadigt, dan zal het lichaam ook proberen om dit wondje te repareren. Dat vraagt om vakmanschap. Immers, indien de trombus maar onbeperkt zou kunnen doorgroelen, dan belemmert hij een goede doorbloeding van de 
kransslagader. Het hart zou hierdoor te weinig voedingsstoffen krijgen en een hartinfarct zou het gevolg zijn. Gelukkig beschikt het lichaam ook over de mogelijkheid om éénmaal gevormie stolsels weer op te lossen. Het mag duidelijk zijn dat er in het lichaam een zeer delicate balans heerst tussen het vormen en het oplossen van bloedstolsels.

Uit onze studies is nu gebleken, dat in vergelijking met enkelvoudig onverzadigde vetzuren, de door ons onderzochte verzadigde vetzuren een ongunstig effect hebben op de tromboseneiging van het bloed [7], De sterk meervoudig onverzadigde vetzuren, die in vis voorkomen, hebben een gunstig effect op de tromboseneiging van het bloed [10]. Deze bevindingen worden ondersteund door dierexperimentele studies [11]. De gevonden effecten van de andere vetzuren en vetbeperking op de tromboseneiging zijn niet éénduidig $[9,12]$. Dit heeft ten dele te maken met het feit, dat onderzoek naar de effecten van voedingsvetten op arteriële trombose zeer moelijk is. Het bloed, dat voor de metingen wordt afgenomen, bevindt zich buiten het lichaam en gedraagt zich daardoor anders dan het bloed in het lichaam. Dit maakt interpretatie van de resultaten moeilijk. Gelukkig komen er steeds meer methoden beschikbaar, die een betere indicatie geven van de arteriële tromboseneiging in het lichaam. Uiteraard zullen wij deze methoden in het toekomstige onderzoek gebruiken. Toch denk ik, dat de huidige resultaten pleiten voor een verlaging van de verzadigd vetzuurconsumptie en een verhoging van de inname van visvetzuren, maar nog steeds niet voor een vetveriaging. Maar waarom zijn vetten dan slecht? Zijn vetten soms dikmakers?

\section{Voedingsvetten en lichaamsgewicht}

Behalve om voedingsvet, maakt de mens zich ook vaak druk om het vet in zijn eigen lichaam. Teveel lichaamsvet leidt tot overgewicht on overgewicht is een risicofactor voor vele welvaartsziekten. Vetweefsel 
dient overigens niet alleen als opslagplaats van energle. Vet is een zeer actief weefsel, waarin continue vetopbouw en vetafbraak plaatsvindt en waar vele stoffen worden gemaakt.

Het is een misvatting, dat het vet cut de voeding rechtstreeks in het lichaamsvet verdwijnt. Er zijn echter wel aanwijzingen, dat de energlebalans moeilijker te handhaven is op een voeding, waarin een hoog percentage van de energie door vet wordt geleverd. Op basis van de resultaten van 16 studies werd geschat, dat voor mensen met overgewicht het verlagen van het energlepercentage vet in de voeding met én procent gepaard gaat met een gewichtsverlies van 400 gram [13]. Het belang van dit effect is moeilijk in te schatten. Misschien dat we Inderdaad lets zullen afvallen, als we vet in de voeding vervangen door koolhydraten. Door dit gewichtsverlies zal het "goede" HDLcholesterolgehalte een beetje stijgen [14]. Echter, ik heb zojuist toegelicht, dat het vervangen van vetzuren in de voeding door koolhydraten een daling van het HDL-cholesterol tot gevolg zal hebben. Het gewichtsverlies en de verlaagde vetconsumptie hebben dus tegengestelde effecten op het HDL-cholesterol en het netto resultaat is, is dat de totaalcholesterol:HDL-cholesterolverhouding in het bloed niet sterk zal veranderen.

Alhoewel het eten van minder vet dus geen krachtige remedie is om overgewicht tegen te gaan, moeten we toch de mogelijke effecten van een geringe verlaging van de huidige vetconsumptie op de gezondheid niet onderschatten. Zo geeft het verlagen van de vetconsumptie de mogelijkheid om gebruik te maken van andere voedingsmiddelen, die een positief effect hebben op de gezondheid, zonder dat dit tot een verhoging van de energieopname leidt. Ook zall het eten van minder vet samengaan met een verminderde hoeveelheid vet in de bloedbaan direct na de maaltijd, hetgeen als gunstig wordt gezien [15]. 
Het is overigens wel zo, dat sommige vetzuren het energiemetabolisme kunnen verhogen. Zelf besteden wij aandacht aan geconjugeerd linolzuur. Hiermee wordt niet zozeer een vetzuur bedoeld, maar een groep vetzuren. Evenals linolzuur hebben zij twee dubbele bindingen, maar dan op andere plaatsen en in een andere vorm. De hoeveelheid geconjugeerd linolzuur in de voeding is slechts een paar honderd milligram. Uit dierexperimenteel onderzoek is nu gebleken, dat het verhogen van de inname van geconjugeerd linolzuur een verlaging van de hoeveelheid lichaamsvet tot gevolg heeft [16]. Of dit voor mensen ook het geval is, is niet duidelijk [17]. In samenwerking met andere onderzoeksgroepen gaan wij nu bekijken of geconjugeerd linolzuur inderdaad een gunstig effect heeft op het percentage lichaamsvet en of er in dit opzicht verschillen bestaan tussen de verschillende vormen geconjugeerd linolzuur. Indien dit zo is, dan zou dit betekenen, dat deze vetzuren een rol kunnen spelen bij het bereiken en handhaven van het gewenste lichaamsgewicht. Maar hier dient zich een probleem aan. De hoeveelheid geconjugeerd linolzuur in voedingsmiddelen zal veel te laag zijn om zo'n effect te bereiken. Dit zou dus betekenen, dat de levensmiddelenindustrie speciale voedingsmiddelen moet ontwikkelen, waaraan geconjugeerd linolzuur moet worden toegevoegd. Hiermee komen we op het terrein van functional foods oftewel functionele voedingsmiddelen.

\section{Functional foods}

De laatste jaren wordt de markt overspoeld met producten, waaraan stoffen zijn toegevoegd, die van nature niet in die hoeveelheden of in dle vorm in het product of in de voeding aanwezig zijn. Deze producten, die functional foods worden genoemd, hebben een positief effect op de gezondheid of lichaamsfuncties. Wij doen ook zelf onderzoek naar stoffen, die een gunstig effect op de gezondheid zouden hebben. Een voorbeeld zijn de tocotriënolen. Dit zijn stoffen dile in de Verenigde 
Staten worden verkocht met de suggestie, dat ze het cholesterolgehalte verlagen. Ik verwacht niet, dat ze in Nederiand als functional foods op de markt komen, want ze werken voor geen meter [18]. Producten, die wel doen wat ze beloven, zijn de margarines, waaraan plantaardige sterolen en stanolen zijn toegevoegd. Dit zijn stoffen, die op cholesterol lijken en de opname van cholesterol in de darm verlagen. Het gevolg is, dat het cholesterolgehalte in het bloed daalt [19]. Ik will nu niet uitvoerig de discussle woeren of functional foods een noodzakelijke aanvulling zijn op de reeds bestaande voedingsmiddelen. Ikzelf vind van wel, maar niet voor iedereen en het moet niet doorschieten. Ook mogen functional foods geen hulpmiddel worden om slechte voedingsgewoonten te corrigeren. Als het mogelijk is om vergelijkbare effecten op lichaamsfunctie of gezondheid te bewerkstelligen door gewoon gebruik te maken van andere gangbare producten, dan moeten we ons afvragen wat de toegevoegde waarde van functional foods is. Functional foods kunnen van nut zijn voor mensen, die voor het krijgen van een bepaalde aandoening een verhoogd risico lopen, maar nog niet hoog genoeg om met geneesmiddelen te worden behandeld. Ook gebruiken sommige mensen liever een voedingsmiddel dan een geneesmiddel. In de zeer nabije toekomst krijgen we dan ook te maken met stoffen, die in grotere hoeveelheden gegeten gaan worden dan dat we tot nu toe gewoon zijn. Dit vraagt om zorgvuldige richtlijnen, voor zowell de periode vóór als de periode na de introductie. Ook vraagt het om zorgvuldig onderzoek. Niet alleen op het punt van veiligheid, maar ook op het punt van werkingsmechanismen en claims. Claims, die aan producten worden toegekend, moeten immers ook waargemaakt kunnen worden en zijn vaak beter te onderbouwen als het werkingsmechanisme van de desbetreffende voedingsstof bekend is. 


\section{Moleculaire voedingskunde}

Tot nu toe heb ik enkele gezondheidskundige aspecten van vetten besproken. Een ander woord voor vetten is lipiden. Met name ben ik ingegaan op de effecten van verschillende vetten op factoren, die een effect hebben op het risico op hart- en vaatzlekten. Deze effecten komen tot stand, omdat zij de stofwisseling beïnvloeden. Een ander woord voor stofwisseling is metabolisme. Mijn onderzoek richt zich dus met name op de vetstofwisseling oftewel het lipidenmetabolisme, waarmee ik tenminste al één woord uit mijn leeropdracht heb toegelicht.

Nu nog het woord "moleculaire voedingskunde".

Ik heb mijn opvatting gegeven of ik deze effecten van vetten als gunstig dan wel als ongunstig beschouw. Deze opvatting is gebaseerd op, zoals ik het soms omschrijf, de zogenaamde input-output benadering: je verandert de inname van één of meerdere voedingsstoffen van een groep mensen en kijkt dan of dit een effect heeft op bijvoorbeeld het gemiddelde cholesterolgehalte van deze groep mensen of het gemiddelde lichaamsgewicht. Ik bedoel dit niet negatief. Dit is een zeer waardevolle benadering, die nodig is en nodig zal blijven, en die haar bestaansrecht meer dan bewezen heeft. De wijze waarop een bepaald effect tot stand komt, heb ik nilet toegelicht.

De benadering van het voedingskundig onderzoek heeft echter in de laatste decennia een stormachtige ontwikkeling doorgemaakt. Door een betere toepasbaarheid in het voedingskundig onderzoek van methoden en technieken van vakgebleden zoals bijvoorbeeld de moleculaire biologie, genetica, biochemie, fysiologie, epidemiologie, toxicologie, voorlichtingskunde, psychologie en marktkunde is het voedingskundig onderzoek steeds verder gedifferentieerd. Dit heeft tot de ontwikkeling geleid van op zichzelf staande vakgebieden, die leder om hun eigen expertise en benadering vragen. Zo bestaat er ook een meer moleculaire benadering van de voedingskundige en de daaraan 
gekoppelde metabole problematiek. Men is zich meer en meer gaan afvragen hoe bepaalde voedingsstoffen werken. De moleculaire voedingskunde probeert dan ook op moleculair en cellulair niveau effecten van voeding op gezondheild en ziekte te verklaren. Dit komt niet alleen omdat de voedingskundige het belang van deze benadering onderkent, maar ook omdat technileken en inzichten aangereikt door de meer fundamentele biomedische disciplines dit nu mogelijk maken. Hierdoor zal de preventie en behandeling van aan voedingsgerelateerde gezondheidsfactoren een meer rationele moleculaire basis kunnen krijgen. Voedingskundigen zijn echter geen moleculair biologen of genetici, maar deze mensen zijn ook geen voedingskundigen. De kracht zal dus in de samenwerking liggen en om elkaars taal te leren spreken. Het is een vakgebied, dat nog maar in de kinderschoenen staat, maar zich in de komende jaren sterk zal ontwikkelen.

Laat ik van het belang; en de mogelijk-en onmogelijkheden, van dit type onderzoek enkele voorbeelden geven.

\section{Essentiële vetzuren}

Het lichaam kan verzadigde en enkelvoudig onverzadigde vetzuren zelf maken. Strikt genomen hoeven wij ze dus niet via de voeding in te nemen. Er zijn echter twee meervoudig onverzadigde vetzuren, die wij wel nodig hebben voor een gezond functioneren, maar die wij niet zelf kunnen maken en die via de voeding moeten worden opgenomen. Dit worden essentiële vetzuren genoemd. Het éne essentiële vetzuur is linolzuur, dat chemisch gezien tot de zogenaamde $(n-6)$ familie behoort; het andere essentiële vetzuur is $\alpha$-linoleenzuur, dat tot de $(n-3)$ familie behoort. Belde essentiële vetzuren kunnen door het menselijke lichaam worden omgezet in andere functionele vetzuren, die een rol spelen bij de stofwisseling.

Enige tijd geleden is gevonden, dat een voeding met een hoog $\alpha$ - 
linoleenzuurgehalte een gunstig effect zou hebben bil de secundaire preventie van coronaire zlekten [20]. Of dit gunstige effect ook daadwerkelijk door het hogere $\alpha$-linoleenzuurgehalte in de voeding kwam, was niet duidelijk. Zo ging de verhoogde inname van $\alpha$ linoleenzuur samen met een verlaagde inname van vet, verzadigd vet, linolzuur en cholesterol, terwijl de inname van ollezuur juist was gestegen. Dit maakte het onmogelijk om de gunstige effecten aan het $\alpha$ linoleenzuur toe te schrijven. Er zijn overigens meer aanwijzingen, dat $\alpha-$ linoleenzuur een gunstig effect heeft op het risico en risicofactoren voor hart- en vaatziekten [21] en nader onderzoek is dan ook dringend gewenst.

Het mogelijke gunstige effect van $\alpha$-linoleenzuur kan misschien ten dele worden verklaard, doordat het lichaam $\alpha$-linoleenzuur omzet in vetzuren, die ook in vette vis voorkomen. Aan deze zogenoemde visvetzuren worden ook vele positieve gezondheidskundige effecten toegekend [22]. Dit zou dus betekenen, dat $\alpha$-linoleenzuur en de visvetzuren vergelijkbare effecten zouden moeten hebben op het risicoprofiel voor hart- en vaatziekten. Wij hebben nu gevonden, dat dit niet zo is. Zo heeft $\alpha$-linoleenzuur bijvoorbeeld niet hetzelfde gunstige effect als visvetzuren op de aggregatie van bloedplaatjes [10]. Ook is nog onbekend hoeveel $\alpha$-linoleenzuur in het menselijk lichaam nu eigenlijk tot visvetzuren wordt omgezet. Stel, dat je nu meer $\alpha$-linoleenzuur gaat eten en de hoeveelheid visvetzuren in het bloed neemt toe, dan geeft dit niet de garantie dat deze vetzuren afkomstig zijn van dit $\alpha$-linoleenzuur. Zo is het bijvoorbeeld ook mogelijk, dat $\alpha$-linoleenzuur juist voorkómt dat de visvetzuren in het bloed worden vrijgemaakt, waardoor ze niet kunnen deelnemen aan die processen, waar ze julst een gunstig effect op hebben. Inzicht in de metabole routes van vetzuren is dan ook onontbeerlijk om hun functies in het lichaam beter te begrijpen. Dit inzicht kan nu worden vergroot door gebruik te maken van stablele isotopen, die in ons onderzoek dan ook een belangrijke rol spelen [23]. 
Stablele isotopen zijn stoffen, die chemisch gezien slechts weinig verschillen van de oorspronkelijke stof. Zij hebben alleen een lets ander gewicht. $Z_{i j} z_{i j n}$ in lage concentraties in de natuur aanwezig en volkomen veilig. Door gebruik te maken van geavanceerde analytische technieken is thet mogelijk om het metabolisme van een stabiel isotoop in het lichaam te volgen. Zo is het bijvoorbeeld mogelijk om, door aan mensen het stabiele isotoop van $\alpha$-linoleenzuur te geven, precies te kwantificeren hoeveel van dit $\alpha$-linoleenzuur als energiebron dient, hoeveel wordt omgezet in de visvetzuren en in welke vetfractie in het bloed het $\alpha$-linoleenzuur en haar omzettingsproducten terecht komen. Wij zijn dit momenteel aan het onderzoeken.

We kunnen echter nog een stap verder gaan. Als we nu weten, dat het metabolisme van $\alpha$-linoleenzuur wordt beïnvloed, dan is natuurlijk de volgende vraag wat hier de achterliggende oorzaak van is.

\section{Genen}

ledere mens is opgebouwd uit miljarden cellen. Een cel is een fabriek op zich en kan vele stoffen maken, zoals bijvoorbeeld de eiwitten en de enzymen die nodig zijin bij de vetstofwisseling. In die cellen bevindt zich een kern, waarin de zogenaamde chromosomen zitten. Een chromosoom is gemaakt van DNA en DNA is weer opgebouwd uit genen. Die genen bevatten nu de erfelijke eigenschappen en de schatting is dat we tienduizenden genen hebben. Genen zijn dus erg machtig, terwill het niet eens vetten zijn! Zo is bijvoorbeeld de kleur van onze ogen genetisch bepaald. Omdat er mensen met blauwe ogen zijn en mensen met bruine ogen, betekent dit dus dat de opbouw van een gen voor ieder mens verschillend kan zijn. Het verschil tussen mensen met blauwe ogen en met bruine ogen is nog gemakkelijk te zien, maar het kan moelilijker. Ergens op het DNA ligt bijvoorbeeld een gen, waarop staat hoe ons lichaam insuline moet maken. Insuline speelt een 
belangrilke rol bij het metabolisme van glucose. Direcl na de maaltij zal het glucosegehalte in het bloed stijgen en het lichaam wil nu dit glucose uit de bloedbaan halen. Dit gebeurt met behulp van insuline. Dit betekent, dat bepaalde cellen, die in de alvleeskller zitten waar het insuline wordt gemaakt, een signaal moeten krijgen, dat zi] insuline moeten maken. Hievoor is het insuline-gen nodig. Vanuit dit gen wordt niel rechtstreeks insuline gemaakt. Eerst wordt vanuit het insuline-gen mRNA gevormd tijdens een proces, dat transcriptie wordt genoemd. Vervolgens dient dit mRNA als mal voor de productie van een eiwit. Dit wordt translatie genoemd. Dit eiwit wordt vervolgens omgezet in insuline, hetgeen wordt aangeduid met posttranslationele modificatie. Ook moeten de cellen in de alvleesklier weer tijdig een signaal krijgen, dat zij geen insuline meer moeten maken. Immers, anders wordt het glucosegehalte in het bloed te laag en komt de brandstofvoorziening van sommige weefsels in gevaar. Er zilin dus heel wat stappen nodig om insuline te maken en weer te laten verdwijnen. Elgenlijk is het wonderbaarlikk, dat het normaal gesproken na elke maaltijd weer goed gaat. Als je het zo bekijkt, dan is eten eigenllik maar een gevaarlijke bezigheid.

De regulatie van sommige metabole processen is bekend. Voor de meeste metabole processen echter niet. Zo is bijvoorbeeld recent pas een zeer belangrijke stap gezet in het onderzoek naar de regulatie op moleculair niveau van de opneming van cholesterol in de darm [24]. Het blijkt, dat er in de darmcel veel meer cholesterol terecht komt dan nodlg. De cell gaat dan bepaalde eiwitten maken, die ervoor zorgen dat het teveel aan cholesterol niet allemaal in de bloedbaan terechthomt. Deze eiwitten sturen een gedeelte van het cholesterol vanuit de darmcel weer gewoon terug naar het darmkanaal, zodat het via de ontlasting kan worden uitgescheiden. $U$ zlet, onze cellen passen goed op ons, maar helaas passen wij vaak wat minder goed op onze cellen. 
Om nu na te gaan welke genen bij dit soort processen betrokken zijn, kan bijvoorbeeld de hoeveelheid mRNA in de cel worden bepaald. Zo zijn wij er bijvoorbeeld achter gekomen, dat het eten van plantaardige stanolen leidt tot een hoger mRNA-gehalte voor de LDL-receptor in de witte bloedcellen. De LDL-receptor is een eiwit dat een belangrijke rol speelt bif het opruimen van het LDL uit de bloedbaan. Dit betrof onderzoek naar de effecten van plantaardige stanolen op de expressie van slechts een beperkt aantal genen, die bij de vetstofwisseling zijn betrokken. Inmiddels zijn er ook technieken, die het mogelijk maken om de regulatie van tienduizenden genen tegelijkertijd te onderzoeken. $\mathrm{Er}$ wordt dan gebruik gemaakt van de zogenaamde DNA-chips. Dit zijn kleine plaatjes, vaak niet groter dan een vingernagel, waarop stoffen zitten die zeer specifiek binden aan het mRNA afkomstig van een bepaald gen. Omdat duizenden, zo niet tienduizenden, verschillende van deze stoffen op een plaatje passen, is het mogelijk om het mANAexpressiepatroon in kaart te brengen. Op deze wijze kan bijvoorbeeld onderzocht worden welke genen actief zijn na een bepaalde voedingsinterventie; of de expressie van die genen voor mensen met overgewicht anders is dan die van mensen zonder overgewicht, en zo zijn nog vele voorbeelden te bedenken. Het is een aantrekkelijke techniek, die ons inzicht kan vergroten op welke wijze voeding fysiologische en biologische processen - en daardoor uiteindelijk gezondheid - beïnvloedt. Zo zou ik me bijvoorbeeld in kunnen denken, dat DNA-chips een onderdeel worden in het onderzoek naar de werkingsmechanismen en veiligheidsaspecten van functional foods. Door de voedingsstof aan celmodellen of proefdieren te geven kan in een kort tijdsbestek een schat aan informatie worden verkregen. Het blift overlgens aan de onderzoeker om de relevantie van deze effecten in te schatten. Ook worden zoveel genen tegelijkertijd bestudeerd, dat de kans dat het expressiepatroon van minstens éen gen verandert, praktisch gelijk is aan één. Je kunt dus gemakkelijk op het verkeerde 
been worden gezet. Ook zijn cellen en dieren geen mensen en het toepassen van deze techniek in het humane voedingsonderzoek ligt moeilijker. Genexpressiepatronen zijn immers weefselafhankelijk en de meeste weetsels, zoals bijvoorbeeld de lever en hersenen, zijn om begrijpelijke redenen niet toegankelijk.

Maar stell dat we nu weten, dat het mRNA-gehalte stijgt, dan nog weten we niet of vanuit dit mRNA ook een functioneel eiwit is gemaakt. Dit is uitermate belangrijk, omdat het uiteindelijk om de eilwitten draait. Als de eiwitten op de verkeerde plaats terecht komen of als er verkeerde eiwitten worden gemaakt $t_{i}$ of als de eiwitten in verkeerde hoeveelheden worden aangemaakt, dan heeft de cel - en daardoor het lichaam - een probleem. Zo hebben wij bijvoorbeeld aangetoond, dat de effecten op mANA-niveau van plantaardige stanolen ook zichtbaar waren op eiwitniveau [25]: Dit was mogelijk door aan de LDL-receptor op de witte bloedcellen een fluorescerende stof te plakken. Deze stof is gemakkelijker te detecteren dan die LDL-receptor zelf.

\section{Genetische gevoeligheid}

Tot slot wil ik het nog even hebben over genetische gevoeligheid. Voor mijn onderzoek betekent dit dat sommige personen meer baat zouden hebben bij een bepaalde voeding dan andere personen. Deze verschillen in gevoeligheid zouden terug te voeren moeten zijn in verschillen in genetische achtergrond. Het belang van de genetische achtergrond zal ik toe lichten aan de hand van een denkbeeldig experiment.

Wat bepaalt nu of $u$ een hoog cholesterolgehalte heeft?

Het cholesterolgehalte in het bloed wordt ten dele bepaald door hetgeen u eet. Daar hoeven we niet aan te twijfelen. Echter, als je 100 mensen opsluit en ze exact hetzelfde levenspatroon oplegt en ze exact dezelfde 
voeding geeft, dan is hel zeer waarschilinijk, dat je 100 verschillende cholesterolwaarden aantreft. Dit komt, omdat iedereen verschillende genen heeft. Het cholesterolgehalte in het bloed is dus ten dele genetisch bepaald.

Als je nu de voeding van deze 100 mensen verandert, dan vind je 100 verschillende veranderingen in het cholesterolgehalte. Met andere woorden, uw genetische achtergrond bepaalt mede op welke wijze uw cholesterolgehalte verandert door uw woedingspatroon te veranderen. $\mathrm{Er}$ is sprake van een gen-voedingsinteractie. Dit betekent, dat de grootte van de cholesteroldaling in het bloed wordt bepaald door de genetische achtergrond en de voeding samen.

Als dit verband echt zo éenduidig en gemakkelijk te onderzoeken is, dan is de volgende stap ook snel gezet: We analyseren de samenstelling van uw genen, zodat we precies weten welke voedingsstoffen voor $u$ geschikt zijn. De samenstelling van de genen zetten we vervolgens op uw klantenkaart van de één of andere supermarkt. Komt u bij de kassa en $u$ hebt toch stiekem margarine in uw winkelwagentje in plaats van de "light" variant, dan gaat het alarm bij de kassa af. ledereen kijkt u aan, u krijgt een aantekening op uw klantenkaart, en een volgende keer past $u$ wel op. U koopt het voedingsmiddel niet meer, alhoewel het ook mogelijk is - wij zijn natuurlijk allemaal erg inventief - dat $u$ de volgende keer de klantenkaart van een buurman gebruikt, die wel margarine mag gebruiken. Wat $\mathrm{kk}$ echter bedoel: zal het mogelijk worden om op individueel niveau voedingsadviezen te geven? Nu gebeurt dat op groepsniveau. $U$ heeft daardoor niet de zekerheid, dat wat goed voor de groep is, ook goed voor $u$ is.

Laten we het experiment nog eens herhalen. We geven die 100 mensen weer dezelfde cholesterolverlagende voeding. Ongetwijfeld zal deze 
keer niet bij iedereen dezelfde cholesterolverlaging optreden als de eerste keer. Dit betekent, dat de genetische achtergrond niet de enige factor is, die van belang is. Het is overigens wel zo, dat - wanneer we dit experiment nog een paar keer herhalen - we wel in staat zullen zijn om mensen te winden die gevoeliger zijn dan andere mensen. Genetische verschillen tussen mensen zijn dus belangrijke oorzaken van variatie in de effecten van voedingsstoffen, maar niet de enige. Andere, vaak nog onbekende factoren, spelen ook een rol. Als dat immers wel zo was, dan zou voor ledereen het cholesterolgehalte de tweede keer in dezelfde mate moeten zijn veranderd als de eerste keer. Ook is het zo, dat die variatie in respons in de meeste gevallen niet terug te voeren zal zijn tot één gen. Er zijn weliswaar ziektebeelden, die zijn toe te wijzen aan een defect van slechts één gen, maar deze zogenaamde monogenetische aandoeningen zijn zeldzaam. Er is niet slechts één gen verantwoordelijk voor hart- en vaatziekten of overgewicht. Het merendeel van de ziekten heeft een polygenetische achtergrond: er zijn meerdere genen bij betroken. Deze genen beïnvloeden dan ook nog eens elkaar en worden beïnvloed door omgevingsfactoren. Dit maakt het dan ook moeilijk om op basis van de genetische constitutie of gen-expressiepatronen van een individu een voedingsadvies te geven. Ook moeten we ervoor waken, dat een voedingsadvies voor een bepaald persoon wel een zeer gunstig effect heeft op het cholesterolgehalte, maar ongunstige effecten heeft op andere gezondheidskundige aspecten.

De populariteit van een voedingskundige zou tot ongeëvenaarde hoogten stijgen, wanneer we in staat zouden zijn om een individueel voedingsadvies te geven, en daarbij ook nog eens een gezondheidsgarantieverklaring konden afgeven. Zo ver zijn we echter nog lang niet en misschien komen we nooit zover. Het geven van voedingsadviezen op maat is wel de uitdaging, die we aan kunnen en aan moeten gaan. Dit vraagt om nieuwe investeringen en om nieuwe initiatieven. 


\section{Dankwoord}

Mijnheer de Rector, Dames en Heren,

Ik houd er mee op. Wel wil ik nog graag enkele woorden van dank uitspreken. Ais eerste wil ik de Stichting Zuivel Voeding en Gezondheid, die mijn bijzonder hoogleraarschap mogelijk heeft gemaakt, bedanken. Zonder ook maar lemand van de Stichting tekort te willen doen, gaat een speciaal woord van dank uit naar Drs Wiebe Visser, de eerste directeur van de Stichting Zuivel Voeding en Gezondheid, die afgelopen zomer op te jonge leeftijd is overleden. Wiebe heeft op zijn eigen wijze het onderzoek - niet alleen in Nederland, maar ook daarbuiten - naar de relatie tussen zuivel, voeding en gezondheid een nieuwe impuls gegeven. Ik ben er inmiddels al van overtuigd, dat deze impulsen ook zullen uitgaan van de nieuwe directeur, Dr Theo Ockhuizen.

De Faculteit der Gezondheidswetenschappen en het College van Bestuur van de Universiteit Maastricht wil ik bedanken voor het in mij gestelde vertrouwen bij mijn benoeming tot bijzonder hoogleraar. Zoals it heb aangegeven, kan de moleculaire voedingskunde zich alleen verder ontwikkelen in een multidisciplinaire omgeving, zoals in Maastricht aanwezig. Ik hoop dan ook op een verdere intensivering van de samenwerking met andere onderzoeksgroepen binnen zowel de Faculteit der Gezondheidswetenschappen, de Faculteit der Geneeskunde, en het Academisch Ziekenhuis.

Ik heb het voorrecht gehad, dat ik gedurende mijn wetenschappelijke bestaan heb mogen werken bij twee uitstekende centra van voedingsonderzoek; die inmiddels verenigd zijn in de onderzoekschool VLAG. 
Hooggeleerde Hornstra, beste Gerard,

Zonder twijfel ben jii degene geweest, die het initiatief heeft genomen om mij in 1990 naar Maastricht te halen. Je stelde me geen vaste aanstelling in het vooruitzicht, want je wilde het niet mooler voorstellen dan het was. Wat je aan je medewerkers belooft, daar zet je je voor in, ook als dat ten koste moet gaan van je eigen gemoedsrust. Wel stelde je me een mooie baan in het vooruitzicht en dat is inderdaad uitgekomen. Je hebt me gecoached waar het nodig was, en me de vrijheid gegeven die ik nodig had. Dat zal niet altijd even gemakkelijk zijn geweest. Je bent echter niet alleen als mens zeer te waarderen, maar ook als wetenschapper. Ik ken maar weinig mensen, die zo innovatief zijn als jij: jij bent één van de grondleggers geweest van de aortaloop om arteriële trombose te kunnen bestuderen; jij hebt mede aan de wieg gestaan van de filtragometer, jij hebt vele nieuwe onderzoekslijnen opgezet. Ik hoop nog lang van je inzichten te mogen profiteren.

Hooggeleerde Katan, beste Martijn,

Nadat ik dankbaar gebruik had gemaakt van de mogelijkheden, die Professor Hautvast mij had geboden om kennis te maken met gedegen voedingsonderzoek, kon ik in 1985 als promotie-assistent bij jou aan de slag. Ik heb een mooie tijd gehad in Wageningen. Ik dank je voor de begeleiding aan het begin van mijn wetenschappelijke loopbaan. Ik heb veel van je geleerd, alhoewel ik sommige dingen pas later begreep. Zo weet ik nog, dat jij eens zuchtend naar een kast keek en zei, dat daarin allemaal goed wetenschappelijk materiaal lag, maar dat je er maar niet aan toekwam om dat op te schrijven. Toen begreep ik dat niet, nu heb ik zelf ook zo'n kast. 
Het voedingsonderzoek heeft zich binnen het onderzoeksinstituut NUTRIM met name kunnen ontwikkelen dankzij de inzet en medewerking van velen.

\section{Hooggeleerde Saris, beste Wim,}

Zonder twijfel ben jij één van de mensen, die aan de basis heeft gestaan van de huidige successen van NUTRIM. Als wetenschappelijk directeur van NUTRIM draag jij de verantwoordelijkheid voor een grote diversiteit aan onderzoek. I heb bewondering voor de manier, waarop je je daarvoor inzet.

Uiteraard ben ik ook de medewerkers van Humane Biologie veel dank schuldig. Ik denk daarbij in de eerste plaats aan de mensen met wie ik nauw samenwerk of samen heb gewerkt: ex-AlO's, AlO's, post-docs, analisten, diëtisten, onderzoeksassistenten en secretariële medewerkers. Zonder jullie inspanningen had ik hier vandaag niet gestaan.

Onderzoek moet gefinancieerd worden en daar zijn subsidiegevers voor nodig. Ik dank dan ook zowel de niet-industriële als industriële partners zoals het NWO, de Nederlandse Hartstichting, de Europese Commissie, de Stichting Zuivel Voeding en Gezondheid, RAISIO, Unilever Research Vlaardingen, en het Wageningen Centre for Food Sciences voor hun bijdragen aan onze onderzoekslijnen.

Tot slot mijn famille. Veel dank ben $i k$ verschuldigd aan mijn ouders. Mijn vader is helaas ruim zeven jaren geleden overieden. Gelukkig is mijn moeder vandaag wel aanwezig. Ma, het kan niet anders, dan dat je af en toe zenuwachtig werd van mijn studiegewoonten: vijftien minuten leren, zestig minuten voetballen. Ikzelf vond het een redelijke verdeling, want een zes was immers voldoende. Met een zes zou ik jou echter tekort doen: jij bent een tien waard. 
Dames en Heren, nog een woord van dank rest mij. Ik heb proberen toe te lichten welke mooie dingen je met voeding en genen kunt onderzoeken. Dat was wetenschap. Voeding en genen zijn echter de basis van nog veel mooiere dingen. Erg blij ben ik dan ook met mijn kinderen: Martijn en Vincent. Jullie zijn meer dan fantastisch en het is een waar genot om jullie dingen te leren, om dingen van jullie te leren, en om jullie te zien opgroeien.

Dianne, met jou sluit ik deze voordracht af. Eerlijk is eerlijk, van jou is de titel van deze voordracht afkomstig. Dat is echter niet het enige, dat je me gegeven hebt. Met elke poging om dat te omschrijven, zou ik je tekort doen.

Daarmee ben ik aan het einde van mijn rede gekomen. Ik hoop dat $u$ veel smakelijke moleculen nuttigt op de receptie.

Ik heb gezegd. 


\section{Referenties}

1. Nederlandse Voedingsnormen 1989. Den Haag: Voorlichtingsbureau voor de Voeding; 1989.

2. Zo eet Nederland. Resultaten van de Voedselconsumptiepeiling 1997-1998. Den Haag: Voedingscentrum; 1998.

3. Keys A, Anderson JT, Grande F. Prediction of serum-cholesterol responses of man to changes in fats in the diet. Lancet $1957 ; 10: 959$ 966.

4. Behandeling en preventie van coronaire hartziekten door verlaging van de plasmacholesterolconcentratie. Concensus cholesterol " tweede herziening. Utrecht: Centraal Begeleidingsorgaan voor de Intercollegiale Toetsing; 1998.

5. Mensink AP, Katan MB. Effect of monounsaturated fatty acids versus complex carbohydrates on high-density lipoproteins in healthy men and women. Lancet 1987; i:122-125.

6. Mensink AP, Katan MB. Effect of a diet enriched with monounsaturated or polyunsaturated fatty acids on levels of lowdensity and high-density lipoprotein cholesterol in healthy women and men. N Engl J Med 1989; 321:436-441.

7. Temme EHM. Individual saturated fatty acids and cardiovascular risk markers. Maastricht: Maastricht University; 1997.

8. Keys A, Anderson JT, Grande F. Serum cholesterol response to changes in the diet. IV. Particular saturated fatty acids in the diet. Metabolism 1965; 14:776-786.

9. Hornstra G, Barth CA, Galli C, et al. Functional food science and the cardiovascular system. Brit J Nutr 1998; 80 (Suppl.11):S113-S146.

10. Wensing AGCL, Mensink RP, Hornstra G. Effects of dietary n-3 polyunsaturated fatty acids from plant and marine origin on platelet aggreglation in healthy elderly subjects. Brit J Nutr 1999; 82:183191.

11. Hornstra $G$, Kester $A D$. Effect of the dietary fat type on arterial thrombosis tendency: systematic studies with a rat model. Atherosclerosis 1997; 13:25-33.

12. Kris-Etherton PM, for the DELTA investigators. Effects of replacing saturated fat (SFA) with monounsaturated fat (MUFA) or carbohydrate $(\mathrm{CHO})$ on plasma lipids and lipoproteins in individuals with markers for insulin-resistance. FASEB J 1996; 10:2666. 
13. Astrup A, Ryan L, Grunwald GK, et al. The role of dietary fat in body fatness: evidence from a preliminary meta-analysis of ad $\|$ ibitum low-fat dietary intervention studies. Brit J Nutr 2000; 83 (Suppl. 1):S25-S32.

14. Yu-Poth $S$, Zhao $G$, Etherton $T$, Naglak $M$, Jonnalagadda $S$, KrisEtherton PM. Effects of the National Cholesterol Education Program's Step | and Step II dietary intervention programs on cardiovascular disease risk factors: a meta-analysis. Am J Clin Nutr 1999; 69:632-646.

15. Goldberg $\mid J$, Kako $Y$, Lutz EP. Responses to eating: lipoproteins, lipolytic products and atherosclerosis. Curr Opin Lipidol 2000; 11: 235-241.

16. DeLany JP, West DB. Changes in body composition with conjugated linoleic acid. J Am Coll Nutr 2000; 19:487S-493S.

17. Zambell $\mathrm{KL}$, Keim NL, Van Loan MD, et al. Conjugated linoleic acid supplementation in humans: effects on body composition and energy expenditure. Lipids 2000;35: 777-782.

18. Kerckhoffs DAJM, Mensink RP, de Bruin TWA, Trautwein EA, Brouns F, Hornstra, $G$. Tocotrienols from rice bran oil have no effects on levels of LDL cholesterol and markers for cholesterol synthesis and absorption. Atherosclerosis 2000; 151:114.

19. Plat $J$, Mensink RP. Vegetable oll based versus wood based stanol ester mixtures: effects on serum lipids and hemostatic factors in non-hypercholesterolemic subjects. Atherosclerosis 2000;148: 101112.

20. de Lorgeril M, Renaud S, Mamelle M, et al. Mediterranean alphalinolenic acid-rich diet in secondary prevention of coronary heart disease. Lancet 1994; 343:1454-1459.

21. Ascherio A, Rimm EB, Giovannucci EL, Splegelman D, Stampfer $M J$, Willett WC. Dietary fat and risk of coronary heart disease in men: cohort follow up study in the United States. Br Med J 1996; 313:84-90.

22. De Deckere EAM, Korver O, Verschuren PM. Katan MB. Health aspects of fish and $n-3$ polyunsaturated fatty acids from plant and marine origin. Eur J Clin Nutr 1998; 52:749-753. 
23. Vermunt SHF, Mensink RP, Simonis MMG, Hornstra, G. Effects of dietary $\alpha$-linolenic acid on the conversion and oxidation of ${ }^{13} \mathrm{C}-\alpha$ linolenic acid. Lipids 2000; 35:137-142.

24. Repa JJ, Turley SD, Lobaccaro J-MA et al. Regulation of absorption and $\mathrm{ABC}-1$ mediated effluX of cholesterol by RXR heterodimers. Sclence 2000; 289:1524-1529.

25. Plat J, Mensink RP. Consumption of plant stanol esters increase LDL receptor expression in mononuclear cells from nonhypercholesterolemic subjects. Atherosclerosis 2000; 151:86. 